\title{
pro.posıções
}

10.1590/1980-6248-2016-0008

$e$-ISSN 1980-6248

DOSSIÊ: Homeschooling e o Direito à Educação

\section{O novo cenário jurisprudencial do direito à educação no Brasil: o ensino domiciliar e outros casos no Supremo Tribunal Federal}

\section{The new jurisprudential panorama of the rights to education in Brazil: homeschooling and other cases in the Supreme Court}

Nina Beatriz Stocco Ranieri (i)

(i) Faculdade de Direito, Universidade de São Paulo (USP), São Paulo, SP, Brasil. nranieri@usp.br

Resumo: A apreciação da constitucionalidade do ensino domiciliar e do ensino religioso confessional em escolas públicas pelo Supremo Tribunal Federal poderá assinalar um ponto de inflexão na jurisprudência educacional, elevando-a a níveis mais complexos de proteção do direito à educação. Se até 2015 as decisões da Corte solucionaram questões relacionadas ao acesso à educação básica, a partir desses casos o STF foi chamado a manifestar-se acerca de direitos instrumentais, relacionados às liberdades na educação e, complementarmente, acerca dos limites da autonomia privada e da intervenção do Estado na educação compulsória. O objetivo deste artigo é apontar a evolução da jurisprudência do STF, no período de 2000 a 2015, suas consequências e implicações.

Palavras-chave: direito à educação, direitos na educação, ensino domiciliar, ensino religioso, judicialização da educação, Supremo Tribunal Federal, Brasil

Abstract: The judicial review of the constitutionality of homeschooling and religious education in public schools could be a turning point in the educational jurisprudence of the Brazilian Supreme Court (STF). In these cases, the Court is demanded to decide on rights related to freedom in education as well as on the limits of state action in compulsory education, in contrast to former decisions aimed at ensuring access to education. The decisions could elevate the jurisprudence to more complex levels of protection of the right to education. The aim of this article is to demonstrate the evolution of the jurisprudence of the STF from 2000 to 2015, its consequences and implications. Keywords: right to education, rights in education, home schooling, religious education, judicialization of education, Brazilian Supreme Court 


\section{pro.posıções}

$e$-ISSN 1980-6248

\section{Introdução}

No ano de 2015, observou-se certa alteração no objeto das ações relativas ao direito à educação no Supremo Tribunal Federal - STF. A temática, apesar de não ser expressiva quantitativamente, centra-se nos chamados direitos na educação e não mais em problemas de acesso e expansão do direito à educação, predominantes na primeira década dos anos 2000.

São significativas dessa mudança duas ações, em particular: (a) a Ação Direta de Inconstitucionalidade (ADI) n. ${ }^{\circ}$ 4.439, proposta pela Procuradoria Geral da República - PGR, referente a compromisso assumido pelo Brasil com a Santa Sé, em 2008, no qual está prevista a oferta de ensino religioso em escolas públicas; e (b) o Recurso Extraordinário (RE) n. o 888.815, referente ao ensino domiciliar, com origem em mandado de segurança impetrado contra ato da secretária de Educação do Município de Canela (RS). Ambas têm como relator o Ministro Roberto Barroso e ainda não foram julgadas.

Nos dois casos, o objetivo é forçar uma atitude abstencionista por parte do Estado, própria das garantias dos direitos individuais de primeira geração. Em relação ao ensino religioso, o objetivo é impedir que o Estado se comprometa com a sua oferta em escolas públicas; já no ensino domiciliar, o objetivo é assegurar sua oferta pela família, sem frequência do aluno a escola pública ou privada. Os argumentos contra o ensino religioso nas escolas públicas fundamentam-se no princípio da laicidade (Constituição Federal [CF] BR, 1988, art. 19, I); no ensino domiciliar, no princípio da liberdade de ensino e concepções pedagógicas (CF BR, 1988, art. 206, II e III), corolários do princípio republicano, que requer tanto a neutralidade do Estado em relação à religião quanto a sua participação, direta ou indireta, na formação de cidadãos, por meio da educação (CF BR, 1988, art. 205).

Por todas essas razões, o julgamento da ADI n. 4.439 e o do RE n..$^{\circ} 888.815$ poderão assinalar um ponto de inflexão na jurisprudência educacional do STF. A tendência, a se confirmar, elevará as decisões da Corte a níveis mais complexos de proteção e promoção do direito à educação.

O objetivo deste artigo é traçar o panorama recente das decisões do STF que provocaram alterações significativas na educação brasileira, no período de 2000 a 2015, com destaque para os casos do ensino domiciliar e do ensino religioso confessional, em escolas 


\section{pro.posıções}

públicas. Começo pelos conceitos básicos acerca do direito à educação; a seguir, trato da jurisprudência educacional.

Evidentemente, as decisões selecionadas não esgotam o tema, mas estão ligadas por denominadores comuns, que permitem reconhecer uma determinada fase. ${ }^{1}$ Esses denominadores são, além do objeto comum, certos elementos de natureza social e institucional. Entre eles se distinguem: um conjunto de demandas análogas, cujo objeto é o acesso a determinado nível educacional; a atuação do Ministério Público; o atendimento de necessidades coletivas, de natureza social e política, com repercussões no plano dos direitos difusos. ${ }^{2}$

\section{Conceitos}

As normas internacionais, a Constituição Federal de 1988 (CF BR, 1988) e a Lei de Diretrizes e Bases de 1996 (Lei BR 9.394, 1996) atribuíram ao direito à educação características jurídicas que o diferenciam em relação aos demais direitos fundamentais ${ }^{3}$. É direito fundamental, de natureza individual, social e coletiva. Os seus titulares e os seus sujeitos passivos são, simultaneamente, uma coisa e outra. Comporta obrigações de fazer e não fazer, por parte de titulares e sujeitos passivos, que não se exaurem e exigem diferentes atendimentos, algumas vezes sob reserva do possível. Seu regime jurídico, portanto, é complexo: envolve diferentes poderes e capacidades de exercício, com a inerente sujeição ao regime jurídico específico dos

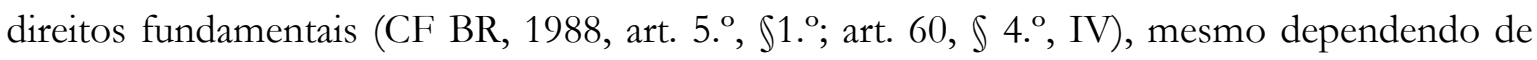
prestações materiais e de recursos financeiros (Ranieri, 2013).

É direito fundamental (direito positivo previsto constitucionalmente), caracterizado pela universalidade, pela igualdade e pela indisponibilidade, com a finalidade de assegurar interesses

\footnotetext{
${ }^{1}$ A sistematização das decisões proferidas pelo STF desde o ano 2000 é metodologicamente problemática. Nem sempre a matéria referente ao direito à educação se encontra classificada como tal; as informações obtidas junto à Assessoria de Gestão Processual dizem respeito à totalidade da entrada de processos, não aos processos julgados; todos os acórdãos são publicados, mas nem todos se encontram disponíveis em versão eletrônica, assim como também não estão disponíveis todas as decisões monocráticas; ou seja, a base eletrônica do STF tem apenas decisões selecionadas.

2 São chamados direitos ou interesses difusos aqueles de que sejam titulares pessoas indeterminadas ligadas por circunstancias de fato. A definição legal é dada pelo art. 81 do Código de Proteção e Defesa do Consumidor (Lei BR 8.078, 1990).

${ }^{3}$ Direitos fundamentais são os direitos consagrados nas Constituições; representam a base ética do sistema jurídico estatal.
} 


\section{pro.posições}

e necessidades identificadas como vitais. Constitui um dos direitos econômicos, sociais e culturais, os chamados direitos humanos de segunda geração, direitos de crédito do indivíduo em relação à coletividade ou direitos de exigir, que exprimem, no sistema jurídico, a exigência de solidariedade. Distinguem-se das liberdades e dos direitos políticos porque representam direitos que se realizam por intermédio da ação do Estado.

No plano individual, o direito à educação prende-se à realização pessoal; nesse sentido, é corolário da dignidade humana e dos princípios da liberdade e da igualdade. No plano coletivo, conecta-se com a vida em sociedade, com a participação política, com o desenvolvimento nacional, com a promoção dos direitos humanos e da paz; ou seja, diz respeito à pessoa inserida num dado contexto social e político. Desse ponto de vista, convém lembrar que a efetividade do direito à educação e suas repercussões beneficiam reciprocamente o indivíduo e a coletividade. Interesse particular e interesse público, assim, se fundem, da mesma forma que os interesses locais, regionais e nacionais.

Não por outras razões, ao contrário dos demais direitos sociais, o direito à educação básica é compulsório, dos 4 aos 17 anos (CF BR, 1988, art. 208, I), não sendo dada aos indivíduos, nesta fase, a opção de exercê-lo ou não; por isso é gratuito e deve ser universalizado. Incluem-se neste nível educacional a Educação Infantil, o Ensino Fundamental e o Ensino Médio. Daí se seguem as correlatas obrigações dos demais sujeitos passivos do direito à educação - o Estado (que deve promovê-lo, protegê-lo e garanti-lo), a família (a quem incumbe promover o acesso à educação) e a sociedade (que o financia) -, traduzidas em deveres também fundamentais.

Tal natureza impacta o conteúdo material do direito à educação. O direito à educação não é ideologicamente neutro. Em vários dispositivos a Constituição assinala sua finalidade, o que denota forte juízo de valor. Conforme se depreende da visão global do sistema constitucional, a difusão e a promoção dos princípios republicano e democrático, como fundamentos do Estado brasileiro, são o conteúdo político nuclear do direito à educação. De fato, se a educação responde, antes de qualquer coisa, a necessidades sociais, sejam elas individuais ou coletivas (CF BR, 1988, art. 205), o seu conceito, no Estado Democrático de Direito, não pode ser desvinculado dos objetivos fundamentais da República (CF BR, 1988, art.3. $^{\circ}$ ). O que significa dizer que, na sistemática da Constituição de 1988, o pleno 


\section{pro.posıções \\ $e$-ISSN 1980-6248}

desenvolvimento da personalidade humana de nenhum modo pode ser desligado da participação na vida da coletividade e no espaço público.

Esse nexo exige a transmissão formal, a cada geração, de todo um conjunto de valores e princípios de extração democrática, por meio do ensino escolar. É o que se extrai, repito, do art. 3. ${ }^{\circ}$, mas também do art. 1. ${ }^{\circ}$ da Constituição Federal (CF BR, 1988), nos quais estão patentes, nomeadamente, a soberania popular, a cidadania, a dignidade humana, os valores sociais do trabalho e da livre iniciativa e o pluralismo político. Essa visão constitui o núcleo do art. 32 da LDB (Lei BR 9.394, 1996), nos seguintes termos: “O ensino fundamental obrigatório, com duração de 9 (nove) anos, gratuito na escola pública, iniciando-se aos 6 anos de idade, terá por objetivo a formação básica do cidadão".

Do ponto de vista jurídico, portanto, a educação é um problema político; um problema que diz respeito à tomada de decisões coletivas, à legitimação e ao exercício do poder nas sociedades contemporâneas.

A forma democrática de vida, diz Anísio Teixeira (1968), em A educação é um direito, "funda-se no pressuposto de que ninguém é tão desprovido de inteligência que não tenha contribuição a fazer às instituições e à sociedade a que pertence” (p. 13). Tal crença, prossegue o autor, equivale a uma hipótese político-social que, para se confirmar, exige da sociedade que ofereça, a todos os indivíduos, acesso aos meios de desenvolver suas capacidades, a fim de habilitá-los à maior participação possível nos atos e nas instituições em que transcorra sua vida, participação que é essencial à sua dignidade de ser humano (p. 14). ${ }^{4}$

No Estado brasileiro, a consciência de pertinência à sociedade estatal é um dos objetivos do direito à educação, social ou individualmente considerado, tal como previsto no art. $6 .^{\circ}$ e no art. 205 da Constituição Federal (CF BR, 1988), neste último com remissão expressa à conexão teleológica entre educação e cidadania que se estabelece em nossa Constituição Federal.

Considerando-se o caráter jurídico das normas constitucionais, consequência especialmente relevante é o fato de que a valoração e os fins da educação, como previstos nos

\footnotetext{
${ }^{4}$ No mesmo sentido argumenta Cury (2002).
} 


\section{pro.posıções}

artigos anteriormente indicados, determinarão o sentido e o alcance de todas as normas jurídicas infraconstitucionais, pautando a argumentação jurídica a ser desenvolvida. ${ }^{5}$

\section{Do direito à educação aos direitos na educação}

A jurisprudência do Supremo Tribunal Federal (STF) sobre o direito à educação ganhou corpo a partir dos anos 2000. Temática relativamente marginal antes da Constituição Federal de 1988, nos 25 anos que se seguiram à sua vigência (entre 1988 e 2013) foram protocolados na Corte mais de 4.000 processos relativos a demandas educacionais, em geral.

Conforme já apontei anteriormente ${ }^{6}$, algumas hipóteses podem explicar o fenômeno desse expressivo aumento de ações: o fortalecimento da proteção do direito à educação, com instrumentos jurídicos adequados à sua efetivação e caracterização do Ensino Fundamental como direito subjetivo público; a ampliação da atividade do Ministério Público pela Constituição (CF BR, 1988, arts. 127 e 129), destacando-se a defesa dos interesses sociais e individuais indisponíveis ${ }^{7}$; e a consolidação da ação civil pública para defesa de interesses coletivos. ${ }^{8}$

Até os anos 2000, raros foram os casos levados à Corte que, diretamente, demandavam tutela para o exercício individual ou coletivo do direito à educação. Na década de 1990, por exemplo, prevaleceram as demandas relativas ao controle de mensalidades escolares, em face da disciplina legal de seu reajuste (Lei BR 8.039, 1990), ao abrigo do art. 173, $\ 44^{\circ}$, da Constituição Federal ${ }^{9}$.

\footnotetext{
${ }^{5}$ Ver, nesse sentido, dentre outros, Barroso (2010).

${ }^{6}$ Ver Nina Ranieri (2008, 2009a, 2009b).

${ }^{7}$ Interesses sociais e individuais indisponíveis dizem respeito ao interesse público, como o direito à vida, por exemplo. São irrenunciáveis e, em regra, intransmissíveis. Ver, nesse sentido, as ações referentes ao direito à vida e à saúde no STF. Exemplificativamente: o RE n. ${ }^{\circ}$ 394.820, Relator o Ministro Carlos Velloso, DJ de 27.5.05; o RE n. ${ }^{\circ}$ 507.927, Relator o Ministro Gilmar Mendes, decisão monocrática, DJ de 6.3.07; e o RE n. ${ }^{\circ}$ 512.889, de que fui Relator, DJ de 12.3.07, entre outros.

8 A ação civil pública é o instrumento processual utilizado para reprimir ou impedir danos ao meio ambiente, ao consumidor, a bens e direitos de valor artístico, estético, histórico, turístico e paisagístico e por infrações de ordem econômica, protegendo, assim, interesses difusos da sociedade, com fundamento na Lei 7.347/85.

${ }^{9}$ Nos casos das mensalidades escolares, na grande maioria das decisões, o STF pronunciou-se favoravelmente à atuação do Estado, firmando jurisprudência no sentido de salvaguardar o direito à educação de abusos econômicos por parte da iniciativa privada, vedando sanções escolares ao inadimplemento de prestações contratuais pelo estudante.
} 


\section{pro.posıções}

10.1590/1980-6248-2016-0008

$e$-ISSN 1980-6248

Tampouco o maior volume de ações educacionais julgadas pelo STF, até o final de 2013, deu-se no campo da defesa de direitos sociais e individuais indisponíveis. No geral, eram ações individuais, voltadas a solucionar controvérsias relativas a transferências de militares e seus efeitos no ensino superior, reconhecimento de diplomas estrangeiros, etc.

Isso conduz ao problema da identificação, nesse conjunto de processos, dos casos educacionais paradigmáticos, que se vinculam uns aos outros, contribuindo para criar jurisprudência. A unidade buscada delineia-se após a criação do Fundef, em 1996. Com o equacionamento das questões relativas ao financiamento e à expansão da educação fundamental por parte dos estados e municípios (alcançando, em muitos casos, a sua universalização), demandas relativas à universalização da Educação Infantil passaram a ocupar a pauta do STF no período 2000-2005. Caso paradigmático é o do Município de Santo André, estado de São Paulo (Agravo Regimental no Recurso Extraordinário 410.715 - 5).$^{10}$

A importância da jurisprudência que solidamente se firmou em relação à Educação Infantil residiu, sobretudo, no fato de estabelecer parâmetros para a efetivação de outras obrigações jurídico-sociais constitucional e internacionalmente impostas, do que decorrem, pelo menos, duas consequências: direitos educacionais são direitos subjetivos ${ }^{11}$, com ampla justiciabilidade; não prestada a garantia, o Estado é considerado infrator daquelas obrigações. ${ }^{12}$

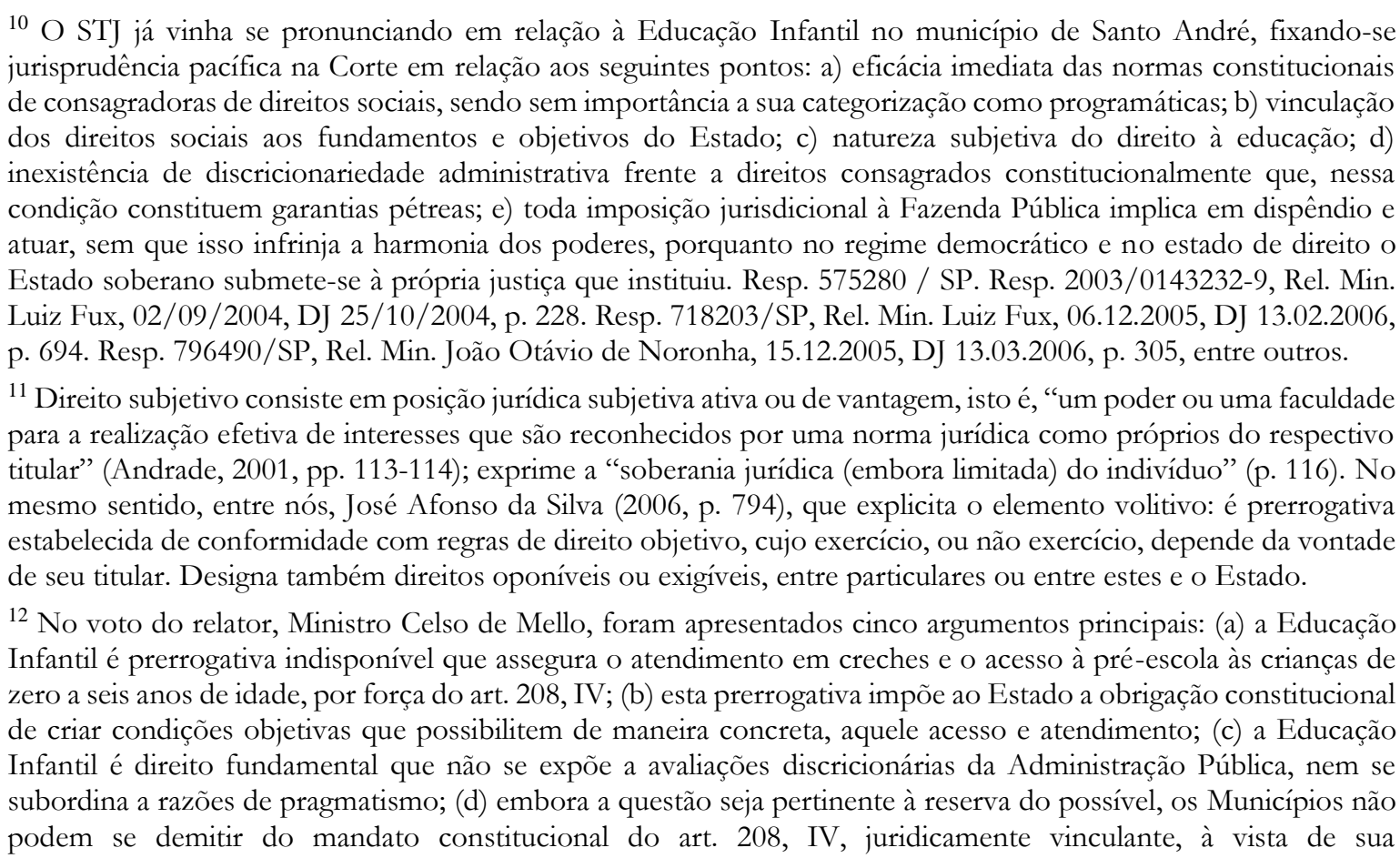




\section{pro.posıções}

10.1590/1980-6248-2016-0008

$e$-ISSN 1980-6248

Esse entendimento, na verdade, não era novo na jurisprudência. Situações de descumprimento de norma impositiva de determinado comportamento atribuído ao Poder Público, já há algum tempo, vinham sendo consideradas inconstitucionais. ${ }^{13} \mathrm{O}$ fundamento inovador, no mencionado caso de Santo André, foi o reconhecimento de que o seu atendimento representava o atendimento de necessidades coletivas, de natureza social e política, com repercussões no plano dos direitos difusos. Não por outras razões, anos depois, a Emenda Constitucional n. ${ }^{\circ}$ 59/2009 (Emenda Constitucional BR, 2009) incluiu a Educação Infantil entre os níveis da educação básica compulsória.

Posteriormente, em 2012, a Corte voltou a influenciar a edição de legislação federal (Lei BR 12.711, 2012), disciplinando a adoção de ações afirmativas pelas universidades federais, após o julgamento da Arguição de Descumprimento de Preceito Fundamental (ADPF) ${ }^{14}$ n. ${ }^{\circ}$ 186/DF e do Recurso Extraordinário (RE) n. ${ }^{0}$ 597.285/RS. Em ambos, o Plenário do STF assentou não haver quebra do princípio da igualdade previsto no art. 5. ${ }^{\circ}$, caput, da Constituição Federal, em face: (i) das políticas de ação afirmativa, (ii) da utilização dessas políticas na seleção para o ingresso no ensino superior, especialmente nas escolas públicas, (iii) do uso do critério étnicoracial por essas políticas, (iv) da autoidentificação como método de seleção e (v) da modalidade de reserva de vagas ou de estabelecimento de cotas, pelo fato de o Estado atribuir a determinados grupos sociais certas vantagens, por tempo limitado, de modo a permitir-lhes a superação de desigualdades decorrentes de situações históricas. ${ }^{15}$

responsabilidade prioritária pelo Ensino Fundamental e pela Educação Infantil (art. 211, \2..$^{\circ}$ ); (e) o Judiciário tem competência para determinar excepcionalmente a implementação de políticas definidas pela própria Constituição por órgãos estatais inadimplentes, cuja omissão pode comprometer a eficácia e a integridade dos direitos sociais; ao não determinar a efetivação desses direitos, o próprio STF estaria incorrendo em grave omissão.

${ }^{13}$ Ver, por todas, no STF, as ADIn 1.458-MC/DF e ADIn 1.484-DF, que têm como Relator Min. Celso de Mello.

14 Tipo de ação disciplinada pela Lei Federal 9.882/99, ajuizada exclusivamente no STF, que tem por objeto evitar ou reparar lesão a preceito fundamental, resultante de ato do Poder Público. Podem ajuizá-la: Presidente da República; Mesa do Senado Federal; Mesa da Câmara dos Deputados; Mesa da Assembleia Legislativa ou da Câmara Legislativa do Distrito Federal Governador de Estado ou do Distrito Federal; Procurador-Geral da República; Conselho Federal da Ordem dos Advogados do Brasil; Partido político com representação no Congresso Nacional; Confederação sindical ou entidade de classe no âmbito nacional. Não é cabível ADPF quando existir outro tipo de ação que possa ser proposto (STF, n.d.).

15 Retirado em 13 de janeiro de 2016, http://redir.stf.jus.br/paginadorpub/paginador.jsp?docTP=TP\&docID=6984693 http://redir.stf.jus.br/paginadorpub/paginador.jsp?docTP=TP\&docID $=5455998$. 


\section{pro.posıções}

$e$-ISSN 1980-6248

Os exemplos anteriores são expressivos. Demonstram, em primeiro lugar, que a interpretação constitucional aponta novos meios de assegurar direitos fundamentais, além de propiciar o seu fortalecimento e influenciar o Legislativo. Em segundo lugar, revelam que, no período em questão, a participação do STF na efetivação do direito à educação foi mais eficiente que a do Legislativo, fato também comprovado por pesquisas temáticas relativas à produção legislativa educacional entre 1995 e $2010 .{ }^{16}$ A propósito, note-se que a jurisprudência do STF, em relação ao direito à educação é materialmente abrangente e não matizada pelos mesmos interesses que atuam em outras instituições democráticas, como o Congresso Nacional, por exemplo, uma vez que a função precípua do órgão é a de guarda da Constituição (responsabilidade finalística).

Mas, se até o momento, prevaleceram, no STF, demandas judiciais relativas ao direito à educação, isto é, demandas relativas a prestações positivas materiais a serem garantidas pelo Estado, como a igualdade de condições para o acesso e a permanência na escola, dentre outras previstas na legislação brasileira, as circunstâncias relativas ao ensino religioso e ao ensino doméstico são inteiramente diferentes. Trata-se, agora, de demandas concernentes a direitos na educação.

De forma sintética, consideremos o direito à educação, previsto no art. 205 da CF (1988) como o gênero do qual os demais direitos educacionais são desdobramentos. O direito à educação (gênero) é, fundamentalmente, um direito de promoção e proteção, realizado mediante ações estatais positivas. Já os direitos na educação (os desdobramentos) têm a função primária de defesa das liberdades no campo da educação, tais como a liberdade de aprender, ensinar, pesquisar e divulgar o pensamento, a arte e o saber; o pluralismo de ideias e de concepções pedagógicas, e a coexistência de instituições públicas e privadas de ensino; a gestão democrática do ensino público (art. 206); o ensino religioso facultativo; a autonomia universitária (art. 207); etc. ${ }^{17}$

${ }^{16}$ A propósito, no âmbito do NUPPS, consultar as pesquisas realizadas por Sara Tironi (2016) e por Michel Lutaif (2013).

${ }^{17}$ No âmbito das Nações Unidas, a diferenciação entre direito à educação, direitos na educação e direitos por meio da educação decorre de interpretação das diferentes previsões dos artigos 13 e 14 do Pacto dos Direitos Econômicos, Sociais e Culturais (PIDESC). No Brasil, o Pacto está em vigência desde 1992 (Decreto BR 591, 1992). A propósito, em matéria de Educação Infantil e Fundamental, consulte-se Children's rights in education (Erickson, Cohen, Hart, \& Flekkoy, 2001). 


\section{pro.posıções}

$e$-ISSN 1980-6248

São direitos de natureza instrumental, que se realizam por intermédio de abstenções estatais e submetidos ao regime das liberdades e garantias, de eficácia plena e aplicabilidade imediata, como todos os direitos fundamentais (Ranieri, 2009a).

Os direitos na educação não constituem outra categoria de direitos sociais. São, igualmente, direitos subjetivos que se traduzem em deveres de proteção (Mendes, 2012, p. 472). Seus fundamentos teóricos podem ser extraídos, conforme o caso, das garantias do direito geral de liberdade ou das dos direitos de liberdades implícitos (Alexy, 2008). No primeiro caso direito geral de liberdade -, tem-se a garantia de um direito explícito, não defeso em lei (isto é, liberdade de ensinar e divulgar o pensamento, previsto no art. 206, II da Constituição [CF BR, 1988]); no segundo caso, um direito de ação (por exemplo, ensino religioso facultativo, art. 210, $\left.\$ 1^{\circ}\right)$, derivado de direito previsto em norma expressa que se identifica com um direito subjetivo, cujo exercício, ou não exercício, depende da vontade de seu titular, desde que essa prerrogativa seja exercida em conformidade com as regras de direito. O problema é o exercício desses direitos em colisão com outras normas constitucionais, a exigir ponderação dos intérpretes.

$\mathrm{Na}$ ADI n. ${ }^{\circ} 4.439$ - caso do ensino religioso - o que está em jogo é a constitucionalidade da oferta de ensino religioso facultativo em escolas públicas, que põe em xeque tanto a laicidade do Estado quanto a liberdade de religião. A PGR questiona a constitucionalidade do $₫ 1 .^{\circ}$, do art. 11 do Decreto n. ${ }^{\circ}$ 7.107/2010, que expressa a ratificação, pelo Congresso Nacional, da Concordata celebrada entre o Brasil e a Santa Sé em 2008, cujo art. 11 prevê a referida oferta. De acordo com a PGR, é vedado à escola pública transformar-se em espaço de catequese e proselitismo religioso, católico ou de qualquer outra confissão. Alega-se, basicamente, que a laicidade impõe ao Estado uma postura neutra em relação às diferentes concepções religiosas presentes na sociedade, sendo-lhe defeso tomar partido em questões de fé, favorecer ou embaraçar qualquer crença, ou grupo de crenças. Por essa razão, a única maneira de viabilizar a laicidade do Estado com o ensino religioso nas escolas públicas seria por via de modelo não confessional, que contemplasse doutrinas e dimensões sociais de diferentes religiões.

No RE n. ${ }^{\circ} 888.815$ - caso do ensino domiciliar -, o problema diz respeito à liberdade de ensino e de concepções pedagógicas. O que está em jogo é a possibilidade legal de determinada criança ser educada em casa. O recurso originou-se em mandado de segurança, indeferido tanto pelo juízo a quo (Comarca de Canela) como pelo Tribunal de Justiça do Estado 


\section{pro.posições}

$e$-ISSN 1980-6248

do Rio Grande do Sul (TJ-RS), com o fundamento de que, não havendo previsão legal de ensino nessa modalidade, não há direito líquido e certo a ser amparado.

A impetrante (a criança em questão) "entende que o convívio com alunos de várias idades não reflete um critério ideal de convivência e socialização, quer por aspectos sociais, quer por aspectos morais, quer por aspectos religiosos e até sexuais" (RE 888.815, 2013, p. 03). Sustenta que

tem condições econômicas de estudar em casa, com a contratação de professores para as diversas disciplinas e se propõe a prestar provas regularmente, mas entende que tem o direito de não freqüentar a Escola porque discorda do sistema convencional e público de educação. (p.04).

Em junho de 2015, o relator promoveu audiência pública sobre o ensino religioso, destinada a ouvir representantes do sistema público de ensino, de grupos religiosos e não religiosos e de outras entidades da sociedade civil, bem como de especialistas no tema, que se manifestaram sobre as seguintes questões: (i) as relações entre o princípio da laicidade do Estado e o ensino religioso nas escolas públicas, (ii) as diferentes posições a respeito dos modelos confessional, interconfessional e não confessional e do impacto de sua adoção sobre os sistemas públicos de ensino e sobre as diversas confissões religiosas e posições não religiosas, e (iii) as diferentes experiências dos sistemas estaduais de educação com o ensino religioso. ${ }^{18}$ No mesmo mês, o relator também admitiu o recurso extraordinário relativo ao ensino domiciliar, nele constatando a existência de repercussão geral ${ }^{19}$, nos seguintes termos: "constitui questão constitucional saber se o ensino domiciliar (homeschooling) pode ser proibido pelo Estado ou viabilizado como meio lícito de cumprimento, pela família, do dever de prover educação, tal como previsto no art. 205 da CRFB/1988", ${ }^{20}$

Diversos problemas emergem nesses casos. Qual o âmbito das liberdades questionadas diante da atuação do Estado? Se, no caso do ensino religioso, o objetivo do governo brasileiro,

18 Retirado em 11 de abril de 2016, de http://www.stf.jus.br/portal/audienciaPublica/ audienciaPublica.asp?tipo $=$ realizada.

${ }^{19}$ A repercussão geral é instrumento processual que permite à Corte selecionar os recursos que apreciará, dada a sua relevância jurídica, política, social ou econômica; julgado o mérito, a decisão no caso específico será aplicada pelas instâncias inferiores em casos idênticos.

20 Retirado em 11 de abril de 2016, de http://www.stf.jus.br/portal/processo/verProcessoAndamento.asp? numero $=888815 \&$ classe $=R E-R G \&$ codigoClasse $=0$ \&origem $=J U R \&$ recurso $=0 \&$ tipoJulgamento $=\mathrm{M}$

file://C:/Users/Usuario/Downloads/texto_307023167.pdf 


\section{pro.posições}

$e$-ISSN 1980-6248

ao celebrar a Concordata, foi ampliar a participação do Estado em área reservada à esfera privada, o do PGR é impedir tal ampliação. Por outro lado, no caso do ensino domiciliar, o objetivo dos pais é ampliar a área de atuação da família, ao pretender oferecer diretamente o Ensino Fundamental à sua filha, enquanto o do Estado é impedir tal ampliação.

Além disso, na garantia dos direitos sociais, genéricos ou instrumentais, são frequentes as colisões de princípios ou de normas, tal como ora ocorre em relação à laicidade e à liberdade de ensino, ou as divergências entre a liberdade de concepções pedagógicas e a educação para a formação do cidadão. Qual deve prevalecer?

Ainda mais sério é o problema da primazia do direito da criança ou do adolescente, em relação ao ensino religioso ou domiciliar. Como aquilatá-la?

O STF, por conseguinte, está sendo chamado a manifestar-se acerca de direitos instrumentais, relacionados às liberdades na educação, e, complementarmente, acerca do papel do Estado. Vejamos por que no julgamento desses casos se discerne a formação de uma nova etapa na jurisprudência da Corte.

\section{A ADI n. ${ }^{\circ} 4.439$ - laicidade estatal e liberdade de ensino}

Estado laico é aquele no qual a atuação governamental é legitimada pela soberania popular e não pelo poder religioso; seu fundamento é a concepção secular, e não sagrada, do poder político. A Constituição da República Federativa do Brasil de 1891 tornou o Estado laico (CF BR, 1891, art. 72, S 6. ${ }^{\circ}$ ), princípio mantido em todas nas demais Constituições de 1934, 1937, 1946, 1967 e 1988 (CF BR, 1988, art. 19, I). ${ }^{21}$

No campo da educação, a laicidade do Estado teve, como consequência imediata, a supressão do ensino religioso nas escolas públicas, a despeito da forte pressão de setores políticos e católicos. $\mathrm{Na}$ Constituição de 1934, tais setores lograram incluir a previsão de oferta do ensino religioso nas escolas públicas, que passou a constar de todos os textos constitucionais subsequentes, sempre em caráter facultativo (note-se que esta é a única menção feita a uma

\footnotetext{
21 “Art. 19- É vedado à União, aos Estados, ao Distrito Federal e aos Municípios: I - estabelecer cultos religiosos ou igrejas, subvencioná-los, embaraçar-lhes o funcionamento ou manter com eles ou suas representantes relações de dependência ou aliança, ressalvada, na forma da lei, a colaboração de interesse público. ”
} 


\section{pro.posıções}

10.1590/1980-6248-2016-0008

$e$-ISSN 1980-6248

determinada disciplina escolar nas Constituições brasileiras). Os princípios da liberdade religiosa e da dignidade da pessoa humana e o repúdio a qualquer forma de discriminação também permearam todas as Constituições brasileiras.

Conjugadas tais disposições ao princípio da laicidade do Estado, a interpretação jurídica prevalecente é a de que o ensino religioso nos estabelecimentos públicos não pode ser confessional. É o que se conclui em face da tradição republicana laica, que veda ao Estado brasileiro tanto o fomento quanto a obstrução de cultos religiosos, de forma a manter o poder público em posição simultânea de imparcialidade e de pluralismo em relação às religiões.

$\mathrm{Na}$ Constituição de 1988, o princípio da igualdade, a liberdade de religião e a liberdade de culto encontram-se assegurados entre os direitos fundamentais (CF BR, 1988, art. 5. ${ }^{\circ}$, VI e VIII). A oferta facultativa de ensino religioso, por sua vez, está restrita ao Ensino Fundamental, nos horários normais de aula $\left(\mathbb{S} 1 .^{\circ}\right.$, art. 210). ${ }^{22}$ A Lei de Diretrizes e Bases da Educação (Lei BR 9.394/1996, art. 33), por seu turno, proíbe, conforme a diretriz constitucional da laicidade, qualquer forma de proselitismo na oferta do ensino religioso ${ }^{23}$ e atribui aos sistemas de ensino estaduais e municipais a competência para definição de conteúdo, bem como para a habilitação e a admissão de professores.

Não é a primeira vez que o STF examina matérias relacionadas à laicidade do Estado. Em temas como a interpretação do alcance da Lei de Biossegurança (ADI 3.510 - caso da utilização de células tronco) e da descriminalização do aborto de fetos anencefálicos (ADPF 54/DF - caso do feto anencefálico), a Corte decidiu com fundamento na laicidade do Estado: "O Brasil é uma república laica, surgindo absolutamente neutro quanto às religiões”.

Também na ADI 2.566 (caso da radiodifusão religiosa), na qual se examinou o alcance da liberdade de expressão adiante da liberdade de crença, o Acórdão proferido registra que

o Estado não tem - nem pode ter - interesses confessionais. Ao Estado é indiferente o conteúdo das ideias religiosas que eventualmente venham circular e a ser pregadas por qualquer grupo confessional, mesmo porque não é lícito ao Poder Público interditá-las ou censurá-las, sem

\footnotetext{
22 “Art. 210 - ... $\int 1 .^{\circ} \mathrm{O}$ ensino religioso, de matrícula facultativa, constituirá disciplina dos horários normais das escolas públicas de ensino fundamental."

23 “Art. 33 - O ensino religioso, de matrícula facultativa, é parte integrante da formação básica do cidadão e constitui disciplina dos horários normais das escolas públicas de ensino fundamental, assegurado o respeito à diversidade cultural religiosa do Brasil, vedadas quaisquer formas de proselitismo. ”
} 


\section{pro.posıções}

incorrer, caso assim venha a agir, em inaceitável interferência em domínio naturalmente estranho às atividades estatais. (p.605)

Tampouco esta é a primeira vez que o STF é chamado a manifestar-se acerca do ensino religioso nas escolas públicas. Na ADI 3.268 (caso do ensino religioso no Rio de Janeiro), por exemplo, ajuizada pela Confederação Nacional dos Trabalhadores, discute-se a constitucionalidade da Lei 3.459/2000, do estado do Rio de Janeiro, que possibilita a oferta de ensino religioso confessional, de acordo com as preferências dos responsáveis pelos alunos. A ação ainda não foi decidida pela Corte.

Em ambas as ações - ADI 3.264 e ADI 4.499 -, várias questões deverão ser examinadas pelo STF: Como interpretar o art. 210, \$1.? Qual a natureza jurídica do ensino religioso/confessional? O que é ensino confessional, em termos legais? No que se distingue de ensino religioso? Como interpretar o art. 33 da LDB? Como definir o conteúdo do ensino religioso/confessional? $\mathrm{O}$ que significa matrícula facultativa (disciplina optativa), em termos legais? Qual o alcance da expressão 'vedadas quaisquer formas de proselitismo'? Quais as soluções possíveis para os sistemas de ensino?

Que princípios e regras serão aplicados? Prevalecerá a laicidade do Estado sobre todos os problemas apontados? Do ponto de vista jurídico, parece não haver alternativa para as escolas públicas senão o ensino de história das religiões.

\section{O RE 888.815: liberdade de ensino e de concepções pedagógicas e a educação para formação do cidadão}

\subsection{A proteção do Ensino Fundamental}

Entre as modalidades da educação básica, o Ensino Fundamental mereceu maior proteção, ao ser qualificado pelo legislador constitucional como direito subjetivo público e rodeado de exigências e garantias específicas (CF BR, 1988, art. 208, I). ${ }^{24}$ Com duração de nove

\footnotetext{
${ }^{24}$ Direito público subjetivo, ou direito subjetivo público, é direito que deriva diretamente da norma constitucional, imediatamente incorporado ao patrimônio do titular e, portanto, direito exigível. Garantias são instrumentos jurídicos destinados a assegurar a fruição dos direitos.
} 


\section{pro.posıções}

$e$-ISSN 1980-6248

anos, inicia-se, obrigatoriamente, aos 6 anos de idade, o que não retira a possibilidade de ser oferecido inclusive para os que a ele não tiveram acesso na idade própria (art. 208, I). ${ }^{25}$ Qualquer cidadão, grupo de cidadãos, associação comunitária, organização sindical, entidade de classe ou outra legalmente constituída e, ainda, o Ministério Público, pode acionar o Poder Público para exigi-lo, sendo gratuita e de rito sumário a ação judicial correspondente (Lei BR 9.394, 1996, art. 5. ${ }^{\circ}$; Lei BR 8.069, 1990, arts. 54 e 208). Sendo interesse social e individual indisponível, sua defesa poderá, ainda, ser objeto de mandado de segurança ou de injunção ${ }^{26}$, em qualquer juízo, instância ou tribunal, estando o Ministério Público legitimado para tanto (Lei BR 8.069 1990, arts. 98, I e 201, IX).

Para o Estado, a natureza específica do Ensino Fundamental determina a primazia e a prioridade do seu atendimento, em relação ao conjunto da educação básica (Lei BR 9.394 1996, art. $5 .^{\circ}, \int 2^{\circ}{ }^{\circ}$. A omissão ou a negligência no seu atendimento importa a responsabilização da autoridade competente (CF BR, 1988, art. 208, \2. ${ }^{\circ}$; Lei BR 8.069, 1990, arts. 98, I e 208, I). Comprovada a negligência, poderá a autoridade competente ser imputada por crime de responsabilidade. Os tribunais também têm determinado a responsabilização civil do Estado por omissão ou negligência na oferta do ensino obrigatório, nesta última hipótese até mesmo em situações de atos lesivos ocasionados ao aluno sob guarda, vigilância e proteção da escola.

Visando assegurar que nenhuma criança deixe de atender ao ensino obrigatório, o legislador constitucional ainda determinou que o Poder Público faça o recenseamento dos educandos e zele, junto aos pais e responsáveis, pela frequência à escola. A obrigação do recenseamento estende-se a jovens e adultos (Lei BR 9.394, 1996, art. 5. ${ }^{\circ}, \mathbb{S} 1$. $^{\circ}$, I; Lei BR 8.069, 1990, art. 98, I). Para garantir o cumprimento da obrigatoriedade de ensino, o Poder Público deverá criar formas alternativas de acesso aos diferentes níveis de ensino, independentemente da escolarização anterior (Lei BR 9.394, 1996, art. 5. ${ }^{\circ}, \mathbb{S}$ 5. ${ }^{\circ}$ ). Cabe ação civil pública contra a Fazenda Pública para assegurar condições de educação (CF BR, 1988, art. 129, III; Lei BR 7.347, de $24 / 07 / 85$, arts. 11 e $\$ 2 .^{\circ}$, e $\left.54, \$ 1 .^{\circ}\right)$.

\footnotetext{
${ }^{25}$ Dois processos judiciais em tramitação no STF questionam o início do Ensino Fundamental aos 6 anos de idade: Ação Direta de Constitucionalidade (ADC) n. ${ }^{\circ} 17$ e Ação de Descumprimento de Preceito Fundamental (ADPF) n. 272.

${ }^{26}$ Mandado de injunção é o processo judicial pelo qual se pede a regulamentação de uma norma da Constituição, quando os Poderes competentes não o fizeram. O pedido é feito para garantir o direito de alguém prejudicado pela omissão (STF, n.d.).
} 


\section{pro.posıções}

$e$-ISSN 1980-6248

Para a família, a natureza jurídica específica do Ensino Fundamental implica a obrigação de efetuar a matrícula dos menores, a partir de 6 anos de idade (CF BR, 1988, arts. 208, \3. $\mathrm{e}$ 227; Lei BR 9.394, 1996, art. 6. ${ }^{\circ}$, Lei BR 8.069, 1990, arts. 4, 22, 98). Cabe ação civil pública contra os próprios pais ou responsáveis (CF, 1988, art. 129, III; Lei BR 7.347, 1985, arts. 129, 155 e 156), em hipótese de descumprimento da norma constitucional, assim como as ações privadas próprias, seja em face de descumprimento das obrigações inerentes ao poder parental (Lei BR, 2002 - Código Civil, art. 1.634), seja em virtude de questões econômicas (proibição do estabelecimento particular de ensino de desligar o aluno em caso de inadimplemento de mensalidades escolares). O Código Penal (Decreto BR, 1940), por sua vez, define, no art. 246, como crime contra a assistência familiar "deixar, sem justa causa, de prover à instrução primária de filho em idade escolar", cominando a pena de "detenção de quinze dias a um mês, ou multa, de vinte centavos a cinquenta centavos".

Sob diferentes argumentos, o que se questiona nos casos judiciais relativos ao ensino domiciliar é, justamente, a força jurídica da proteção atribuída ao Ensino Fundamental como direito de cidadania, potencializada pela obrigatoriedade de atendimento por parte da criança e da família. O caso paradigmático, até o momento, é o conhecido Mandado de Segurança (MS) n. ${ }^{\circ}$ 7.407-DF, impetrado junto ao Superior Tribunal de Justiça. ${ }^{27}$

\subsection{Antecedentes: o Mandado de Segurança (MS) n. ${ }^{\circ}$ 7.407-DF}

O caso consistiu na apreciação, pelo Superior Tribunal de Justiça - STJ, de mandado de segurança individual impetrado contra ato do Ministro da Educação que homologou o Parecer n. ${ }^{\circ}$ 34/2000 da Câmara de Ensino Básico do Conselho Nacional de Educação (CEB/CNE). Este parecer havia negado a pretensão de que menores, em idade de matricularem-se no Ensino Fundamental, fossem educados por seus pais no recesso do lar e independentemente de frequência a estabelecimento de ensino. Propunham que o estabelecimento avaliasse os conhecimentos ministrados no lar, por ocasião das provas regularmente aplicadas aos demais alunos. Os pais (os impetrantes), em verdade, jamais haviam matriculado os filhos em escolas.

${ }^{27} \mathrm{O}$ mandado de segurança individual é um recurso jurídico, previsto no art. 5. ${ }^{\circ}$, LXIX, da Constituição Federal, destinado a proteger direito líquido e certo, não protegido por habeas corpus ou habeas data, quando o responsável pela ilegalidade ou abuso de poder for autoridade pública ou agente de pessoa jurídica no exercício de atribuição do poder público. 


\section{pro.posıções}

Obrigados a fazê-lo, por força do art. 208, $\int 3 .^{\circ}$ da Constituição Federal, foi necessário realizar avaliação prévia, nos termos do art. 24 , II, "c" da LDB, ocasião em que se constatou que as crianças apresentavam conhecimentos formais além do exigido nas séries correspondentes às suas idades. Por essas razões de fato é que os pais solicitaram a autorização para prosseguir nos ensinamentos, tal como haviam feito até então.

Nesse caso, foram apreciadas diversas questões relacionadas aos direitos fundamentais, nomeadamente: o direito à educação, os direitos da família, os direitos das crianças e adolescentes, o dever do Estado e da família no oferecimento da educação e suas relações com os direitos de liberdade de aprender, ensinar, pesquisar e divulgar o pensamento, a arte e o saber; a prevalência do poder parental na escolha da educação a ser oferecida aos filhos; as repercussões penais da não matrícula escolar. Mas o que estava em jogo, fundamentalmente, era o primado da família sobre o Estado, como base da sociedade (CF BR, 1988, art. 226), vis à vis a obrigação constitucional de atendimento do Ensino Fundamental em instituições escolares.

Os fundamentos da decisão do STJ centraram-se, basicamente, em três aspectos principais: a) a frequência à escola é direito dos menores, previsto na Constituição Federal e regulamentado pela Lei de Diretrizes e Bases da Educação e pelo Estatuto da Criança (Lei BR 8.069, 1990). Tal regulamento não pode ser desafiado pela convicção filosófica dos pais; b) mesmo reconhecida, a capacidade dos pais para ministrar boa educação não basta para privar a criança do direito ao convívio escolar; c) não pode o Poder Judiciário desprezar o ordenamento jurídico em favor da convicção política e filosófica dos pais.

As principais objeções levantadas nos votos vencidos deram ênfase à prevalência da família sobre o Estado, sob a invocação do art. 226 da Constituição Federal (1988) e do art. 26.3 da Declaração Universal dos Direitos do Homem - DUDH 1948 -, que declara pertencer aos pais a prioridade do direito de escolher o gênero de educação a dar aos filhos. Outro argumento, menos consistente, foi a invocação da ausência de proibição legal expressa de oferecimento de ensino domiciliar, com remissão a diversos dispositivos da LDB (Lei BR, 1996) acerca da frequência obrigatória às aulas, relativizando-os retoricamente, o que deixaria entrever a possibilidade (art. $1 .^{\circ}, \S 1 .{ }^{\circ}$; art. $24, \mathrm{II} \mathrm{e} \mathrm{VI} \mathrm{c/c} \mathrm{art.} \mathrm{32,} \mathrm{\} 4 .^{\circ}$ ). 


\section{pro.posıções}

No voto do Relator, sobreleva notar a definição da precedência do Estado sobre a família nesta matéria específica. A fundamentação reside na exigência da formação da cidadania em espaço público, aqui considerada direito das crianças.

De acordo com a decisão do STJ, portanto, o direito à educação fundamental obrigatória encerra dois direitos de cidadania: o direito à formação que o Ensino Fundamental propicia e o direito de recebê-lo em estabelecimento de Ensino Fundamental, público ou privado. O fundamento axiológico do direito de cidadania assim expresso concentra-se, pois, na ideia do inter sum, que se concretiza, em sua inteireza, no espaço público, local onde se realiza a pluralidade resultante das relações humanas que envolvem o outro e, por consequência, onde se expressa a solidariedade.

De outra parte, confirma-se judicialmente que o nexo entre o indivíduo e a participação na vida coletiva e no espaço público requer a transmissão formal, a cada geração, de todo um conjunto de valores e princípios de extração democrática, por meio do ensino escolar. É o que se extrai, repetimos, do art. 3. ${ }^{\circ}$, mas também do art. 1. ${ }^{\circ}$ da Constituição Federal (CF BR, 1988), nos quais estão patentes, nomeadamente, a soberania popular, a cidadania, a dignidade humana, os valores sociais do trabalho e da livre iniciativa e o pluralismo político.

Da premissa do dúplice conteúdo do direito à educação fundamental decorrem três conclusões: as obrigações da família com o Ensino Fundamental em relação a seus filhos têm caráter complementar às obrigações do Estado; os deveres dos pais, neste nível fundamental, não são excepcionáveis à luz da liberdade de ensino nem da pluralidade de concepções pedagógicas, a ponto de facultar o ensino domiciliar, nem há exceções à frequência escolar (CF BR, 1988, art. 208, \4. ${ }^{\circ}$.

É o que se confirma diante da letra do inciso III, do art. 206 da CF (CF BR, 1988): garantia de coexistência de escolas públicas e privadas, estas últimas classificadas e conceituadas pela LDB (Lei BR 9.394, 1996), em seu artigo 20. De fato, nem na CF, nem na LDB, há menção, entre as escolas privadas, da educação doméstica ou familiar.

A liberdade de ensino e de orientação pedagógica, portanto, concerne à escolha entre a escola pública ou a privada, ao método pedagógico da educação formal e à eventual orientação religiosa, dentre outras possíveis opções, mas não entre ensino formal e informal. De outra parte, se já eram evidentes as limitações ao pátrio poder e à prevalência da família em razão das 


\section{pro.posições}

normas de proteção da criança e do adolescente, a decisão do STJ definiu mais uma, a de extração constitucional.

Este caso revela, igualmente, a singular posição do Estado em relação ao direito à educação, no qual se apresenta, simultaneamente, sujeito passivo e titular. Não por outras razões, o Ensino Fundamental e o alistamento eleitoral são obrigatórios (CF BR, 1988, art. 14, I). O princípio da soberania popular impõe deveres. E, ainda que do voto obrigatório possam ser excepcionados os analfabetos, os maiores de 16 anos e menores de 18 anos, nenhum deles foi dispensado do ensino obrigatório. Os efeitos do alistamento eleitoral e da matrícula no Ensino Fundamental também são distintos: alistado, o eleitor pode comparecer ou não à respectiva zona eleitoral e, em comparecendo, pode votar, votar em branco ou anular o voto; no Ensino Fundamental, diversamente, matriculado, o aluno deve comparecer à escola.

As raras exceções ficam por conta de situações nas quais a saúde do indivíduo não lhe permite a frequência à escola. ${ }^{28}$

\subsection{O RE 888.815 como hard-case?}

A doutrina jurídica norte-americana utiliza a denominação hard cases, casos difíceis, para identificar ações judiciais que não podem ser submetidas a uma regra de direito clara, de forma que o juiz tem maior discricionariedade para indicar a solução jurídica do problema social apresentado (Dworkin, 2002, p. 127).

Ao discorrer sobre o tema da discricionariedade judicial em face de hard-cases em outra oportunidade (Ranieri, 2011), apontei que a temática:

suscitou diferentes posições na doutrina americana, sendo conhecida a divergência entre H. L. A. Hart (The concept of law, 1961) e Ronald Dworkin (Taking rights seriously, 1977) sobre a existência ou não de um dever legal do juiz de decidir de determinada maneira em situações de incompletude da lei. ${ }^{29}$

Em apertada síntese, podemos dizer que, para Hart, como o direito positivo deve responder a todas as situações suscitadas judicialmente, o juiz, nos casos difíceis, dispõe de maior

\footnotetext{
${ }^{28}$ Ver, por exemplo, Agravo de Instrumento n. ${ }^{\circ}$ 70021769534/2007, Tribunal de Justiça/RS.

${ }^{29}$ A obra de Hart, em português: Hart, H. L. A. (2007). O conceito de Direito (5a ed.). Lisboa: Fundação Calouste Gulbenkian.
} 


\section{pro.posições}

discricionariedade (ou "discricionariedade forte", na tipologia de Dworkin), dada a incompletude ou lacuna da lei. Para Dworkin, diversamente, o juiz dispõe apenas de "discricionariedade fraca", dado "o dever de descobrir quais são aos direitos das partes e não inventar outros direitos retroativamente". Essa problemática, em Hart, não é uma preocupação, posto que tais direitos, em face da lacuna legal, não existiriam, razão pela qual não se estaria desconsiderando qualquer direito. Note-se que Dworkin não diverge de Hart no tocante à discricionariedade fraca, mas [contrapõe-se] tão somente à discricionariedade forte. E isso porque a sua reflexão política, ainda que de matriz liberal, não reduz o âmbito político à defesa de direitos e à representação de interesses privados, pois considera antes a liberdade de autodeterminação dos indivíduos e a realização do bem comum.

Essas posições são ilustrativas da diferença substantiva entre hard-cases e leading-cases no sistema jurídico americano, no que diz respeito às influências externas à Constituição, vis a vis o grau da discricionariedade judicial que pode ser adotado pelo juiz.

De modo geral, no direito norte-americano, o emprego da expressão hard-case refere-se a uma causa que sofre os impactos de uma razão social avassaladora, que "apela aos sentimentos do julgador e distorce o julgamento", para usar as palavras do controvertido Oliver Wendell Holmes Jr., Associate Justice da Suprema Corte no início do século XX (citado em Posner, 1992, p. 30). Por essa razão, a discricionariedade do julgador, motivada por ideias de reparação, pode levar à elaboração de decisões não conformadas aos true principles of law, como nos adverte Henry Campbell Black (1990, p. 771). Hard-cases make bad law, enfatizam, sem relativizações, Black e Holmes.

Nos leading-cases, o problema da "discricionariedade forte" não se apresenta, posto que a solução indicada para o caso, ainda que resultante de "discricionariedade fraca", encontra amparo nas normas constitucionais. A grande contribuição do leading-case, ao solucionar um caso difícil, consiste em fixar novas linhas interpretativas que ampliam a garantia e a proteção do direito.

Podemos dizer, portanto, que soluções fundadas em ampla discricionariedade judicial seriam, a princípio, mais discutíveis do ponto de vista técnico-jurídico, o que relativizaria a observância, pelo juiz, dos limites de sua função e, em consequência, poria em xeque a legitimidade dessas decisões no âmbito do Estado Democrático de Direito. Trata-se, nesta hipótese, do ativismo judicial entendido como "desrespeito aos limites normativos substanciais da função jurisdicional”, conforme a sintética definição de Elival da Silva Ramos (2010, p. 109) em alentada obra sobre o tema. (pp. 60-61)

Toda essa problemática assume especial relevância, quando se trata de casos difíceis relativos a matéria constitucional, uma vez que a jurisdição constitucional é o último nível de controle das normas constitucionais e consequência da adoção de Constituições rígidas, dotadas de superioridade hierárquica, como é a Constituição brasileira.

Qual a relação entre hard-cases e leading-cases e a decisão a ser proferida pelo STF no RE 888.815? Seria este um hard-case? 


\section{pro.posıções}

$e$-ISSN 1980-6248

Parece que não. Em primeiro lugar, porque a matéria sub judice não difere da do caso do MS 7.407. Estamos, igualmente, diante de discussão que envolve o dever do Estado e da família no oferecimento da educação e suas relações com os direitos de liberdade de aprender, ensinar, pesquisar e divulgar o pensamento, a arte e o saber; a prevalência do poder parental na escolha da educação a ser oferecida aos filhos; as repercussões penais da não matrícula escolar; os limites da autonomia privada contra imposições estatais. Não há fatos novos que justificassem apreciação distinta. Na verdade, o MS 7.407 é um leading-case ${ }^{30}$, para continuar com as expressões norte-americanas. Isso porque sua solução para o caso difícil encontra amparo nas normas constitucionais, fixando novas linhas interpretativas que ampliam a garantia e a proteção do direito.

Em segundo lugar, porque, também nesse caso, há prevalência do princípio da primazia da criança sobre o poder parental, por força da ratificação da Convenção dos Direitos das Crianças - CDC -, promulgada no Brasil pelo Decreto n. ${ }^{0}$ 99.710/90 (Decreto BR, 1990). ${ }^{31}$ Dificilmente, salvo situações de absoluta impossibilidade de frequência à escola, prevalecerá o argumento de que o ensino domiciliar é mais favorável à criança. Prova disso é a exigência legal de matrícula e frequência de alunos com necessidades especiais em escolas regulares (Lei BR $9.394,1996$, arts. 58 e 59$)$.

Por outro lado, não se pode desconhecer que a própria legislação insinua a existência de algumas brechas nesse arcabouço. A LDB (Lei BR 9.394, 1996), por exemplo, admite a classificação do aluno em qualquer série ou etapa, exceto a do primeiro ano do Ensino Fundamental, independentemente de escolarização anterior, mediante avaliação feita pela escola, conforme regulamentação do respectivo sistema de ensino (art. 24, II, c). O que significa dizer que, a qualquer momento, o aluno poderá ingressar na escola regular, admitidos como válidos os conhecimentos adquiridos em ensino domiciliar, de acordo com os resultados da avaliação.

Além disso, é possível obter certificado de conclusão do Ensino Médio mediante aprovação no Exame Nacional do Ensino Médio - ENEM -, conforme Portaria n. o 807/2010,

\footnotetext{
${ }^{30}$ Já as expressões standard-case e leading-case, utilizadas como sinônimas em língua inglesa, podem ser traduzidas para o português como "caso paradigmático" e "caso líder", respectivamente. Um caso paradigmático sempre decorrerá de uma causa difícil ou problemática, embora um caso difícil nem sempre se torne um caso paradigmático.

31 “Art. 3. ${ }^{\circ}$ 1. Todas as ações relativas às crianças, levadas a efeito por autoridades administrativas ou órgãos legislativos, devem considerar, primordialmente, o interesse maior da criança ”. (Decreto BR, 99.710, 1990)
} 


\section{pro.posıções}

$e$-ISSN 1980-6248

do Ministério da Educação, atendidos os requisitos do art. 38, II da LDB e demais exigências legais, particularmente a idade mínima de 18 anos. Anote-se, porém, que a regra vem sendo interpretada pelos Tribunais de modo restritivo, posto ser excepcional e aplicável apenas aos maiores de 18 anos que não completaram o Ensino Médio em idade apropriada, em consonância com a finalidade do instituto da educação supletiva. ${ }^{32}$ Em outras palavras, a alternativa não aproveitaria àqueles que não se matricularam em escolas regulares, a menos que realizassem o ENEM com mais de 18 anos, sob o manto da educação supletiva.

Como se pode observar, diante de todas essas questões, as controvérsias sempre envolvem o âmbito e os limites da relação Estado/liberdade individual na educação.

Chama atenção, contudo, o argumento econômico utilizado pelo Ministro Barroso para atribuir repercussão geral ao RE 888.815 (STF, 2015):

O debate apresenta repercussão geral, especialmente do ponto de vista social, jurídico e econômico: social, em razão da própria natureza do direito pleiteado; jurídico, porque relacionado à interpretação e alcance das normas constitucionais que preveem a liberdade de ensino e o pluralismo de ideias e concepções pedagógicas e à definição dos limites da relação entre Estado e família na promoção do direito fundamental à educação; e econômico, tendo em conta que, segundo estudos o reconhecimento do bomeschooling poderia reduzir os gastos públicos com a educação.

O argumento não é sustável. Embora não seja o caso de aqui se aprofundar a estrutura do financiamento da educação pública no Brasil, basta lembrar que a educação pública compulsória, em todos os níveis e modalidades, é mantida com vinculação de recursos tributários (CF BR,1988, 167, IV e 212) e fundo orçamentário, de natureza redistributiva (o Fundo de Manutenção do Ensino Básico - Fundeb, ADCT, art. 60), sob rígido controle. Ora, a magnitude desses recursos é elevada, sendo notório o fato de que as discussões em torno dos problemas de financiamento da educação no País respeitam mais à qualidade dos gastos do que à sua quantidade. Difícil imaginar, por conseguinte, que o bomeschooling pudesse reduzir gastos públicos, em benefício da qualidade de sua aplicação, a não ser que superasse, em grande escala, as matrículas escolares.

32 A jurisprudência vem se firmando nesse sentido, a despeito de decisões isoladas em sentido contrário. Ver STJ, RMS 36545 (2012). 


\section{pro.posıções

\subsection{Em conclusão: a inflexão na jurisprudência educacional do STF}

Apontamos que, no ano de 2015, deram entrada no STF recursos relativos aos chamados direitos na educação, cujos objetos e tutelas requeridas divergem daqueles relativos à garantia de acesso e expansão da educação básica, predominantes na atuação da Corte primeira década dos anos 2000. São eles: (a) a Ação Direta de Inconstitucionalidade (ADI) n. ${ }^{\circ}$ 4.439, proposta pela Procuradoria Geral da República - PGR -, referente a compromisso assumido pelo Brasil com a Santa Sé, em 2008, no qual está prevista a oferta de ensino religioso em escolas públicas; e (b) o Recurso Extraordinário (RE) n. ${ }^{\circ} 888.815$, referente ao ensino domiciliar, com origem em mandado de segurança impetrado contra ato da secretária de Educação do Município de Canela (RS).

Nos dois casos, o objetivo é forçar uma atitude abstencionista por parte do Estado: no ensino religioso, impedir que o Estado se comprometa com a sua oferta em escolas públicas; no ensino domiciliar, assegurar sua oferta pela família, sem frequência do aluno à escola pública ou privada. Os argumentos contra o ensino religioso nas escolas públicas fundamentam-se no princípio da laicidade (CF BR, 1988, art. 19, I); no ensino domiciliar, no princípio da liberdade de ensino e concepções pedagógicas (CF BR, 1988, art. 206, II e III), corolários do princípio republicano, que tanto requer a neutralidade do Estado em relação à religião quanto a sua participação, direta ou indireta, na formação de cidadãos, por meio da educação (CF BR, 1988, art. 205). O ponto central, em ambos, reside na fixação, pela Corte, dos limites da autonomia privada diante do Estado, no campo da educação.

Como vimos, até então, a jurisprudência do STF vinha se debruçando sobre problemas coletivos, em matéria de acesso e permanência na educação básica, particularmente em relação à Educação Infantil. A jurisprudência que solidamente se firmou estabeleceu que direitos educacionais são direitos subjetivos, com ampla justiciabilidade, a exigir a prestação pelo Estado em caso de sua não garantia. Além do atendimento de necessidades coletivas, de natureza social e política, com repercussões no plano dos direitos difusos, a jurisprudência do STF provocou, posteriormente, a aprovação da Emenda Constitucional n. ${ }^{\circ}$ 59/2009, que incluiu a Educação Infantil entre os níveis da educação básica compulsória. O que significa dizer que a interpretação constitucional apontou novos meios de se assegurarem direitos fundamentais, além de ter propiciado o seu fortalecimento e influenciado o Legislativo. 


\section{pro.posıções}

$e$-ISSN 1980-6248

Estamos, agora, diante de novo contexto: não se trata de obrigar o Poder Público a assegurar prestações estatais positivas de fazer alguma coisa (traduzidas na garantia material de acesso ou permanência na educação básica), mas de assegurar liberdades individuais na educação, por meio de proteções estatais (traduzidas na permissão do ensino domiciliar ou na do ensino religioso confessional, em escolas públicas). A prestação estatal ora solicitada ao STF é, pois, diversa da prevalecente no início dos anos 2000.

Nos dois recursos, os temas são complementares: liberdade religiosa e ensino domiciliar requerem abstenção do Estado e ampliação da esfera de liberdade individual. Um realça o outro, um reforça o outro, pois implicam posições ideológicas, na mesma direção do que faz - de outra forma - o projeto de lei da denominada "Escola sem Partido", em tramitação no Senado ${ }^{33}$, cujas motivações e justificativas guardam analogia com os argumentos apresentados no RE n. ${ }^{\circ}$ 888.815 (ensino domiciliar). A meu ver, a ocorrência dos recursos extraordinários em questão não se deve a mera coincidência cronológica, mas decorre de movimento social - incipiente, porém significativo - em direção ao fortalecimento das liberdades na educação. Isso não significa, por evidente, a superação de problemas recorrentes da educação pública brasileira tais como acesso, permanência, financiamento e qualidade -, mas maior facilidade de acesso ao Judiciário, para algumas camadas da população.

Do ponto de vista jurídico, o que está em jogo são diversas colisões de princípios e normas a serem apreciadas pela Corte: laicidade e liberdade de ensino, liberdade de concepções pedagógicas e educação para a formação do cidadão. Qual deve prevalecer? Como aquilatar o problema da primazia do direito da criança ou do adolescente, em relação ao ensino religioso ou domiciliar? Qual a natureza jurídica do ensino religioso/confessional? Qual a natureza jurídica do dever da família em relação à educação compulsória? Que princípios e regras serão aplicados? Prevalecerá a liberdade individual ou a intervenção do Estado sobre todos os problemas apontados?

Em síntese, e para concluir, toda a problemática jurídica do ensino domiciliar e do ensino religioso assume especial relevância, por envolver matéria constitucional e estar sob a apreciação do STF, último nível de controle jurisdicional. Sua decisão poderá assinalar, como

\footnotetext{
33 Projeto de lei 193, de 2016. Autoria do Senador Magno Malta. Inclui entre as diretrizes e bases da educação nacional, de que trata a Lei n. ${ }^{\text {9.394, de }} 20$ de dezembro de 1996, o "Programa Escola sem Partido".
} 


\section{pro.posições \\ $e$-ISSN 1980-6248}

disse de início, a inflexão na jurisprudência da Corte, elevando-a a níveis mais complexos de proteção e promoção do direito à educação: não teremos o atendimento de necessidades coletivas, de natureza social e política, com repercussões no plano dos direitos difusos, mas a fixação, definitiva, dos limites da autonomia privada diante do Estado, no campo da educação pública. O que não é pouco. ${ }^{34}$

\footnotetext{
34 Até $1^{\circ}$ de agosto de 2017, o STF não havia decidido nenhum dos casos analisados neste artigo. De acordo com a página eletrônica do Tribunal, a ADI 4439 tinha previsão de julgamento para 23/8/2017; o RE 888.815, por sua vez, não apresentava qualquer previsão de julgamento. Retirado em 01 de agosto de 2017, de http://www.stf.jus.br/portal/processo/verProcessoAndamento.asp?incidente $=4774632$.
} 


\section{pro.posições}

10.1590/1980-6248-2016-0008

\section{Referências}

Alexy, R. Teoria dos direitos fundamentais (Virgílio Afonso da Silva, trad.). São Paulo: Malheiros, 2008.

Andrade, J. C. V. de. (2001). Os direitos fundamentais na Constituição Portuguesa de 1976. Coimbra: Almedina.

Barroso, L. R. (2010). Curso de Direito Constitucional contemporâneo - os conceitos fundamentais e a construção do novo modelo. São Paulo: Saraiva.

Black, H. C. (1990). Black's law dictionary (6a ed.). St. Paul, Minn.: West Publishing.

Cury, C. R. J. (2002, julho). Direito à educação: direito à igualdade, direito à diferença. Cadernos de Pesquisa, 116, pp. 245-262. Retirado em 15 de novembro de 2016, de http://www.scielo.br/scielo.php. doi: 10.1590/S0100-15742002000200010.

Dworkin, R. (2002). Levando os direitos a sério. São Paulo: Martins Fontes.

Erickson, M. F., Cohen, C. P., Hart, S., \& Flekkoy, M. (Eds.). (2001). Children's rights in education. London and Philadelphia: Jessica Kingsley Publishers.

Hart, H. L. A. (2007). O conceito de Direito (5a ed.). Lisboa: Fundação Calouste Gulbenkian.

Lutaif, M. (2013). Brasil, 25 anos de democracia e politicas públicas para o direito à educação - Análise dos projetos de lei não aprovados no Congresso Nacional entre 1995 e 2010. Relatório final de pesquisa de iniciação científica, apresentado à Comissão de Pesquisa da Faculdade de Direito da Universidade de São Paulo.

Mendes, G. (2012). Direitos fundamentais e controle de constitucionalidade. Estudos de Direito Constitucional. São Paulo: Saraiva.

Posner, R. A. (Ed.). (1992). The essential Holmes. Chicago, IL: The University of Chicago Press.

Ramos, E. da S. (2010). Ativismo judicial: parâmetros dogmáticos. São Paulo: Saraiva.

Ranieri, N. (2008). Os estados e o direito à Educação na Constituição de 1988 - Comentários acerca da jurisprudência do Supremo Tribunal Federal. In A. de Moraes (Org.), Os 20 anos da constituição da República Federativa do Brasil (p.183). São Paulo: Atlas. 


\section{pro.posıções \\ $e$-ISSN 1980-6248}

10.1590/1980-6248-2016-0008

Ranieri, N. (2009a). O estado democrático de direito e o sentido da exigência de preparo da pessoa para o exercício da cidadania, pela via da educação. Tese de Livre-Docência, Faculdade de Direito da Universidade de São Paulo.

Ranieri, N. (2009b). O Supremo Tribunal Federal e o Direito Internacional da Educação. In A. do Amaral Junior, \& L. Jubilut (Orgs.), O STF e o Direito Internacional dos Direitos Humanos. São Paulo: Quartier Latin.

Ranieri, N. (2011). Hard-cases $e$ leading-cases no campo do direito à educação: o caso das quotas raciais (Coleção Doutrinas Essenciais de Direitos Humanos, vol. 4, p. 59). São Paulo: Ed. Revista dos Tribunais.

Ranieri, N. B. S. (2013). O direito educacional no sistema jurídico brasileiro. In ABMP - Todos pela Educação, Justiça pela qualidade na educação (pp. 55-103, 819 pp.). São Paulo: Saraiva.

Silva, José Afonso da (2006). Comentários Contextuais à Constituição. São Paulo: Malheiros.

Supremo Tribunal Federal. (2015). Recurso com repercussão geral discute direito dos pais de educar filhos em casa. Notícias STF. Brasília. Retirado em 26 de janeiro de 2016, de http://www.stf.jus.br/portal/cms/verNoticiaDetalhe.asp?idConteudo=293490\&caixa Busca $=\mathrm{N}$.

Supremo Tribunal Federal. (n.d.). Glossário jurídico. Mandado de injunção. Retirado em 18 de novembro de 2016, de http://www.stf.jus.br/portal/glossario/verVerbete.asp?letra=M\&id=188

Supremo Tribunal Federal. (n.d.). Glossário jurídico. Arguição de Descumprimento de Preceito Fundamental. Retirado em 18 de novembro de 2016, de http://www.stf.jus.br/portal/glossario/verVerbete.asp?letra=M\&id=188

Teixeira, A. (1968). A educação é um direito. São Paulo: Cia. Editora Nacional,

Tironi, S. (2016). Políticas públicas para a educação infantil: análise da atividade legislativa do Congresso Nacional para o setor entre 2001 e 2010. Dissertação de Mestrado, Faculdade de Direito da Universidade de São Paulo. 


\section{pro.posições \\ $e$-ISSN 1980-6248}

\section{Legislação}

Constituição da República Federativa do Brasil de 1891 (1891). Brasília: Presidência da República. Casa Civil. Subchefia para Assuntos Jurídicos.

Constituição da República Federativa do Brasil de 1988 (1988). Brasília: Presidência da República. Casa Civil. Subchefia para Assuntos Jurídicos.

Declaração Universal dos Direitos do Homem (1948). Brasília: Presidência da República. Casa Civil. Subchefia para Assuntos Jurídicos.

Decreto-lei BR n. ${ }^{\circ} 2.848$, de 7 de dezembro de 1940. Institui o Código Penal. Diário Oficial da União, 7 de dezembro de 1940. Rio de Janeiro: Presidência da República. Casa Civil. Subchefia para Assuntos Jurídicos.

Decreto BR n. ${ }^{\circ}$ 99.710, de 21 de novembro de 1990. Promulga a Convenção sobre os Direitos da Criança. Diário Oficial da União, 22 de novembro de 1990, Seção 1, página 22256. Brasília: Presidência da República. Casa Civil. Subchefia para Assuntos Jurídicos.

Decreto BR $n .{ }^{\circ} 591$, de 6 de julho de 1992. Atos Internacionais. Pacto Internacional sobre Direitos Econômicos, Sociais e Culturais. Promulgação. Diário Oficial da União, 7 de julho de 1992, Seção 1, p. 8713. Brasília: Presidência da República. Casa Civil. Subchefia para Assuntos Jurídicos.

Emenda Constitucional BR $n^{\circ}$ 59, de 11 de novembro de 2009. Presidência da República. Casa Civil. Subchefia para Assuntos Jurídicos.

Lei BR $n .^{\circ} 7.347$, de 24 de julho de 1985. Disciplina a ação civil pública de responsabilidade por danos causados ao meio ambiente, ao consumidor, a bens e direitos de valor artístico, estético, histórico e paisagístico e dá outras providências.

Lei BR $n .^{\circ} 8.039$, de 30 de maio de 1990. Dispõe sobre critérios de reajuste das mensalidades escolares e dá outras providências. Diário Oficial da União, 30 de maio de 1990. Brasília: Presidência da República. Casa Civil. Subchefia para Assuntos Jurídicos.

Lei BR n. ${ }^{\circ}$ 8.069, de 13 de julho de 1990. Dispõe sobre o Estatuto da Criança e do Adolescente e dá outras providências. Presidência da República. Casa Civil. Subchefia para Assuntos Jurídicos. 


\section{pro.posıções \\ $e$-ISSN 1980-6248}

Lei BR n. ${ }^{\circ}$ 9.394, de 20 de dezembro de 1996. Estabelece as diretrizes e bases da educação nacional. Diário Oficial da União, 20 de dezembro de 1996. Brasília: Presidência da República. Casa Civil. Subchefia para Assuntos Jurídicos.

Lei BR n. ${ }^{\circ}$ 10.406, de 10 de janeiro de 2002. Institui o Código Civil. Diário Oficial da União, 10 de janeiro de 2002. Brasília: Presidência da República. Casa Civil. Subchefia para Assuntos Jurídicos.

Lei BR $n .^{\circ} 12.711$, de 29 de agosto de 2012. Dispõe sobre o ingresso nas universidades federais e nas instituições federais de ensino técnico de nível médio e dá outras providências. Diário Oficial da União, 29 de agosto de 2012. Brasília: Presidência da República. Casa Civil. Subchefia para Assuntos Jurídicos.

Portaria BR MEC n. ${ }^{\circ}$ 807, de 18/06/2010. Institui o Exame Nacional do Ensino Médio - ENEM como procedimento de avaliação cujo objetivo é aferir se o participante do Exame, ao final do ensino médio, demonstra domínio dos princípios científicos e tecnológicos que presidem a produção moderna e conhecimento das formas contemporâneas de linguagem. Diário Oficial da União, 21 de junho de 2010. Brasília: Ministério da Educação.

\section{Casos Judiciais citados}

\section{Supremo Tribunal Federal}

Ação Direta de Constitucionalidade (ADC) no 17-MS (2008), Rel. Min. Edson Fachin.

Ação Direta de Inconstitucionalidade (ADI) no 4439-DF (2010), Rel. Min. Roberto Barroso.

Ação Direta de Inconstitucionalidade (ADI) n ${ }^{\circ}$ 1.458-DF, Rel. Min. Sepúlveda Pertence. Diário da Justiça, 31de outubro de 2001.

Ação Direta de Inconstitucionalidade (ADI) n. 1.484-DF, Rel. Min. Celso de Mello. Diário da Justiça, 28 de agosto de 2001.

Ação Direta de Inconstitucionalidade (ADI) n² 2566-0, DF. Rel. Min. Teori Zavaski. Julgamento em 25 de maio de 2002. Tribunal Pleno. Retirado em 13 de janeiro de 2016, de http://redir.stf.jus.br/paginadorpub/paginador.jsp?docTP=AC\&docID=347623 


\section{pro.posıções \\ $e$-ISSN 1980-6248}

Agravo Regimental no Recurso Extraordinário (Agr. Reg.) 410.715 - 5, município de Santo André. Rel. Min. Celso de Mello. Julgamento em 22/11/2005. Segunda Turma. Retirado em 13 de janeiro de 2016, de http://www.stf.jus.br/portal/geral/verPdfPaginado.asp?id=354801\&tipo=AC\&descri cao $=$ Inteiro $\% 20$ Teor $\% 20 \mathrm{RE} \% 20 / \% 20410715 \% 20-\% 20 \mathrm{AgR}$

Arguição de Descumprimento de Preceito Fundamental (ADPF) n. ${ }^{\circ}$ 186/DF. Rel. Min. Ricardo Lewandowski. Julgamento em 26/04/2012. Tribunal Pleno. Retirado em 13 de janeiro de 2016, de http:/ /redir.stf.jus.br/paginadorpub/paginador.jsp?docTP=TP\&docID=6984693.

Arguição de Descumprimento de Preceito Fundamental (ADPF) no 54. Julgamento em 12 de abril de 2012. Rel. Min. Marco Aurélio. Plenário. Diário da Justiça, 30 de abril de 2013. Retirado em 13 de janeiro de 2016, de http://www.stf.jus.br/arquivo/cms/publicacaoLegislacaoAnotada/anexo/constituica o.PDF.

Arguição de Descumprimento de Preceito Fundamental (ADPF) no 272-SP (2013). Rel. Min. Cármen Lúcia.

Recurso Extraordinário (RE) n. ${ }^{\circ}$ 597.285/RS. Rel. Min. Ricardo Lewandowski, Julgado em 09/05/2012. Tribunal Pleno. Retirado em 13 de janeiro de 2016, de http://redir.stf.jus.br/paginadorpub/paginador.jsp?docTP=TP\&docID=5455998.

Recurso Extraordinário (RE) n. ${ }^{\circ}$ 394.820, Rel. Min. Carlos Velloso, DJ de 27.5.05.

Recurso Extraordinário (RE) n. ${ }^{\circ}$ 507.927, Rel. Min. Gilmar Mendes, decisão monocrática, DJ de 6.3.07.

Recurso Extraordinário (RE) no 888815-RS (2015). Rel. Min. Roberto Barroso. Petição inicial. Retirado em 12 de janeiro de 2016, de http://redir.stf.jus.br/estfvisualizadorpub/jsp/consultarprocessoeletronico/Consultar ProcessoEletronico.jsf?seqobjetoincidente $=4774632$. 


\section{pro.posıções

\section{Superior Tribunal de Justiça}

Recurso em Mandado de Segurança (RMS) nº 36.545. Rel. Min. Humberto Martins. Julgamento em 01 de março de 2012. Segunda Turma. Diário da Justiça, 07 de março de 2012.

Recurso Especial (Resp.) no 796.490/SP. Rel. Min. João Otávio de Noronha, 15.12.2005, Diário da Justiça, 13 de março de 2006, p. 305.

Recurso Especial (Resp.) no 575.280 / SP (2003). Rel. Min. José Delgado. Julgamento em 02 de setembro de 2004. Diário da Justiça, 25 de outubro de 2004, p. 228.

Recurso Especial (Resp.) no 0.143.232-9. Rel. Min. Luiz Fux, em 02 de setembro de 2004. Diário da Justiça, 25 de outubro de 2004, p. 228.

Recurso Especial (Resp.) n 718.203/SP. Rel. Min. Luiz Fux, em 06 de dezembro de 2005. Diário da Justiça, 13 de fevereiro de 2006, p. 694.

Mandado de Segurança (MS) n. ${ }^{\circ}$ 7.407-DF. Rel. Min. Francisco Peçanha Martins. Julgamento em 24/04/2002. Diário da Justiça, 21 de março de 2005, p. 203.

\section{Tribunais Estaduais}

Agravo de Instrumento (Agr.) n. ${ }^{\circ}$ 70021769534/2007. Tribunal de Justiça/RS.

Retirado em 13 de janeiro de 2016, de http://www1.tjrs.jus.br/site_php/consulta/consulta_processo.php?

Submetido à avaliação em 19 de novembro de 2016; revisado em 13 de outubro de 2016; aceito para publicação em 04 de março de 2017. 